\title{
Designing interactive games for improving elementary school students' number sense
}

\author{
Neni Hermita ${ }^{1}$, Jesi Alexander Alim ${ }^{1}$, Zetra Hainul Putra ${ }^{1}$, Peggi \\ Muharrani Gusti ${ }^{1}$, Tommy Tanu Wijaya2 ${ }^{2}$, Jerito Pereira ${ }^{3}$ \\ ${ }^{1}$ University of Riau, Indonesia. \\ ${ }^{2}$ School of Mathematical Sciences, Beijing Normal University, Tiongkok. \\ ${ }^{3}$ Department of Mathematics and Statistics, Guangxi Normal University, Tiongkok. \\ $₫$ tanuwijayat@gmail.com
}

\section{Article Information}

Submitted Oct 02, 2021

Revised Nov 07, 2021

Accepted Nov 20, 2021

\section{Keywords}

Genially;

Interactive Media Learning;

Number Sense;

Interactive Game.

\begin{abstract}
Number sense is an essential primary mathematics material in elementary school that students must master. Learning media may be utilized in elementary schools' teaching and learning process to engage and inspire students to participate in learning activities, particularly mathematics. Therefore, the researchers designed an interactive game using Genially to improve students' number sense. The ADDIE development model was applied in the research and development procedure. In this research, the ADDIE development model began by analyzing problems related to the mathematics learning process in elementary schools, analyzing the environment and work situation, designing an interactive game, developing the game based on validation results from three media experts and two concept experts, and conducting a one-on-one trial. The product feasibility was tested on 46 students who were divided into two classes. Class B served as the experimental class, while Class A served as the control class. The interactive game's validation findings showed that the developed interactive learning media was practical and useful. As a result of the implementation, the experimental class students' grasp the material better than the control class.
\end{abstract}

\section{INTRODUCTION}

Mathematics is one of the subjects taught at the elementary, middle, and high school levels (Kulsum et al., 2019; Rahmah, 2013). Mathematics learning is a process to obtain knowledge and understand the meaning of the mathematical structures, relationships, and symbols that causes students' behavioral changes since mathematics learning starts from the easiest to the most complicated (Chen, 2020; Mukminin et al., 2019; Nur, 2004).

Mathematics learning tends to memorize concepts, definitions and apply formulas without understanding the meaning of the contents. According to Wijaya (Wijaya et al., 2020), if students memorize formulas, they will get different types of questions and find it difficult to solve the problem. This tendency will certainly affect the students' problemsolving skills in mathematics (De Losada, 2017; Nite, 2017; Rohaeti et al., 2019). Furthermore, mathematics is not a lesson to memorize formulas, but students must understand the meaning of the questions (Kurniasi et al., 2020). Therefore, it is necessary to change activities in mathematics learning.

The students are not only always taught how to apply formulas or rules to answer questions correctly. They have to learn about the meaning of numbers and mastery of numbers because good number mastery can support problem-solving skills and support 
activities in everyday life (Hermita et al., 2018; Kulsum et al., 2019). Number mastery is called number sense or sensitivity to numbers (Sood \& Mackey, 2015).

Number sense, also known as numerical sensitivity, helps students understand numbers, number operations, and the capacity to interpret flexibly in making mathematical judgments and generate helpful and efficient ways to deal with numerical challenges (McIntosh et al., 1992; Mcintosh et al., 1997). In this case, the elementary school students' number sense is not only based on the information provided by the teacher in class, but students can also find this ability by using learning media that are packaged and designed in such a way by the teacher so that they can understand and find it individually.

In this research, the developed media used was interactive learning media. Interactive learning media uses personal computers to make text, graphics, audio, and moving images that allow users to interact and communicate (Lainufar et al., 2020; Euis et al., 2019; Yuniarni et al., 2020). Wijaya et al. (Wijaya et al., 2020) designed interactive learning media with dynamic mathematics software and showed that interactive learning media could help students enhance their creative thinking skills (Pereira et al., 2021; Wijaya et al., 2020). Furthermore, interactive learning media increased students' motivation in mathematics learning (Putra et al., 2021; Ruqoyyah et al., 2020). Interactive learning media do not always have to use difficult software. Microsoft Excel can also be a fun interactive learning media (Euis et al., 2019; Wijaya et al., 2020). Interactive learning media have been widely developed at the junior high and high school levels (Baharuddin, 2018; Harits et al., 2019; Prabowo et al., 2018). However, little research has been conducted to produce interactive learning media in elementary schools, particularly for number sense material.

Interactive learning media may be created by utilizing a variety of apps, one of which is Genially. Genial.ly is an online service that creates visually appealing and engaging interactive content in posters, games, interactive material, and infographics (Dzenskevich, 2020). Previous research has been used Genially to improve students' experience, collaboration skills, and motivation in learning (Vidergor, 2021). Not only in mathematics, Genialy can also be used in other subjects (Musskopf et al., 2019). Genially can be used as a visual laboratory for a blended learning (Manuel et al., 2019). It is a website that can help researchers and teachers create interactive learning media whose results can improve the quality of education and students' abilities, help students like a subject, and help teachers deliver the material.

Previous research analyzed the effect of number sense on students' learning outcomes in Iran and on students' problem solving (Mutmainnah et al., 2021). Several studies show that there are significant differences when elementary school students do not understand master number sense. Research by Maghfirah and Mahmudi (Maghfirah \& Mahmudi, 2018) qualitatively describes the meaning and components of number sense. Their research also explains the relationship between number sense and students' arithmetic abilities. Thus, it can be concluded that previous research focused more on qualitative and quantitative research to see the relationship between number sense and students' learning outcomes. However, it is still uncommon to research the development of technology-based learning media in the number sense.

The researchers considered that number sense is an important lesson that students must master based on their background. The researchers considered that the development of 
interactive learning media using Genially could improve students' number sense. This research focused on developing an interactive game to improve the number sense of elementary school students. The developed game is a dynamic number card game where students must find answers to the questions. Education experts and teachers have evaluated the development of this interactive game to improve existing deficiencies so that the game is suitable to be used by students in the learning process.

\section{METHODS}

The ADDIE model (Analysis, Design, Development, Implementation, and Evaluation) was used in this research and development. The ADDIE paradigm is used to foster studentcentered, innovative, and creative learning. It provides students with real-world experiences. (Cabang, 2009). The development procedure is shown in Figure 1.

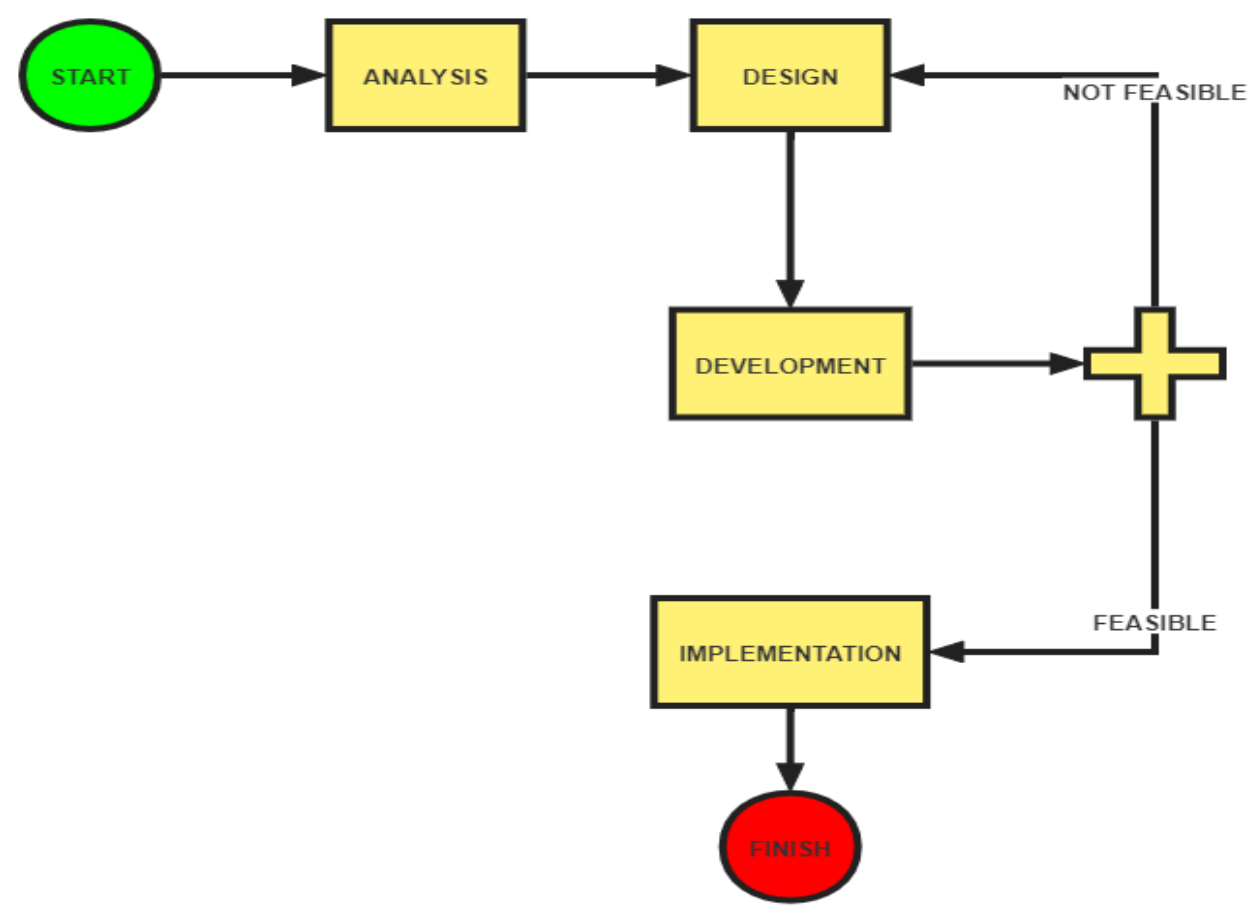

Figure 1. The ADDIE Development Model

\section{Analysis Stage}

The analysis stage is related to analysis activities on work situations and the environment to determine what products need to be developed (Sugiyono, 2019). In this research, the researchers analyzed the problems experienced by students and teachers where teachers rarely used learning media and did not apply the concept of number sense in learning activities. After obtaining the problem, the researchers looked for solutions to overcome mathematics learning problems in elementary schools by developing interactive learning media.

Curriculum analysis, analysis of student characteristics, and analysis of material are needed before developing the media. The development of interactive learning media with the dynamic card game concept aligned with the first-grade curriculum. The material for recognizing numbers in elementary school starts from numbers 1-20. From existing learning indicators, the researchers chose material for comparison and ordering numbers 1-10 to be developed with the game concept. First-grade students have the characteristics of 
understanding learning by concrete things. Therefore, the researchers presented the closest objects that students in everyday life often encounter.

\section{Design and Development Stage}

The dynamic card game was first designed in Microsoft Word to avoid errors during the development. The pictures of vehicles, fruits, fingers, food, and professions presented were chosen to represent numbers based on the initial aim of this research, namely to improve students' number sense.

The dynamic card game was created using Genially application. This application enables users to run games on Android devices and personal computers. The first thing to do was design the game display consisting of a welcome sentence, the developer's profile, the relevant agencies, and a button to continue the game. When the users press the button, they will be given information regarding what functions are used for the buttons presented. On the next page, the media will display the title of the material and a button to select the game menu.

When the button is pressed, the media will display menu buttons of Quantity, Comparison, Sorting, and Instructions. To start the game, the user can select the Quantity, Comparison, or Sorting buttons. The Quantity section is an initial number recognition where the user is asked to count the number of the objects on the card and choose the presented numbers. There are three stages in this section. If the users choose the number correctly, then the user is given an award in the form of a winning animation, and the user can continue to the next stage. If the users choose the wrong number, then the user will be given a sad cartoon animation and has to try again.

Students must compare two cards with varied numbers of items in the Comparison section, whether they are lower, the same, or higher. There are ten stages in this comparison section. Similar to the Quantity section, if the user answers correctly, he will be given an award and can continue to the next stage, and if he answers incorrectly, he will have to try again. Three stages are given in the Sorting section. The sorting order is located at the top screen. For the first problem, the user is asked to sort three cards. In the second problem, the user is tasked to sort four cards, and the last problem asks the user to sort five cards. When all the games have been completed, the media displays a thank you note.

Before the implementation stage, the researchers validated the media through media experts and material experts validation. Media validation is comprised of two types of evaluation: design/display evaluation and technical evaluation. Furthermore, the material validation consisted of two components evaluation: the pedagogical aspect and the content aspect. The validation was done to determine how well students in the classroom perceive the dynamic card game learning media. Table 1 presents the decision-making.

Table 1. Category of the Decision Making

\begin{tabular}{cc}
\hline Interval of average Score $(\boldsymbol{\%})$ & Categories \\
\hline $84<\mathrm{x} \leq 100$ & Excellent \\
\hline $68<\mathrm{x} \leq 84$ & High \\
\hline $52<\mathrm{x} \leq 68$ & Quite High \\
\hline $36<\mathrm{x} \leq 52$ & Moderate \\
\hline $20<\mathrm{x} \leq 36$ & Low \\
\hline
\end{tabular}




\section{Implementation and Evaluation Stage}

Researchers conducted a one-on-one test on three first-grade elementary school students to see the practicality and feasibility of the developed media. Forty-six first-grade students performed the implementation stage at SDN 192 Pekanbaru. The students were divided into two classes. The students were required to run the media during the implementation stage. Upon completion, the students were requested to respond to questions presented by the researchers.

\section{RESULTS AND DISCUSSION}

This research and development were conducted using the ADDIE development model to produce an internet-based interactive learning media with Genially applications. This research involved the main developer, three media expert validators, two material expert validators, teachers, and students in obtaining valid and appropriate final results. Teachers can use this media as a resource in mathematics learning for first-grade elementary school students. Genially application combines text, graphics, video, animation, sound, and buttons into a single unit that the user can operate. The media flowchart is explained in Table 2.

\section{Features of the Interactive Game}

Table 2. The Flowchart of the Interactive Game

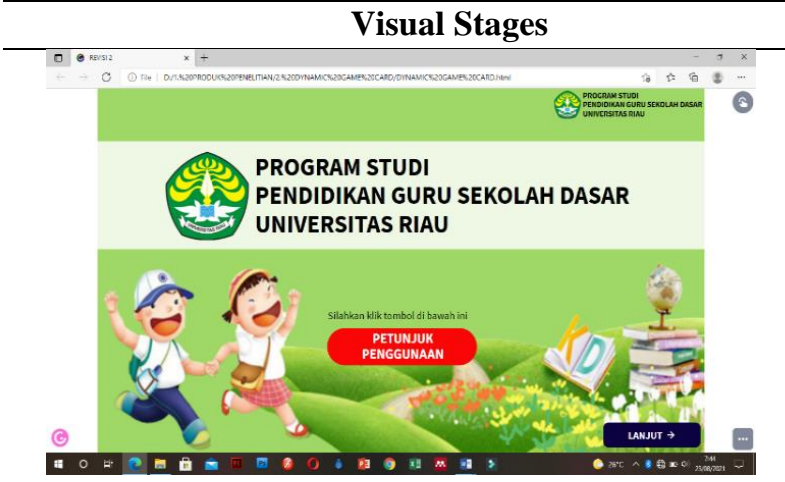

Figure 1. Presentation Page

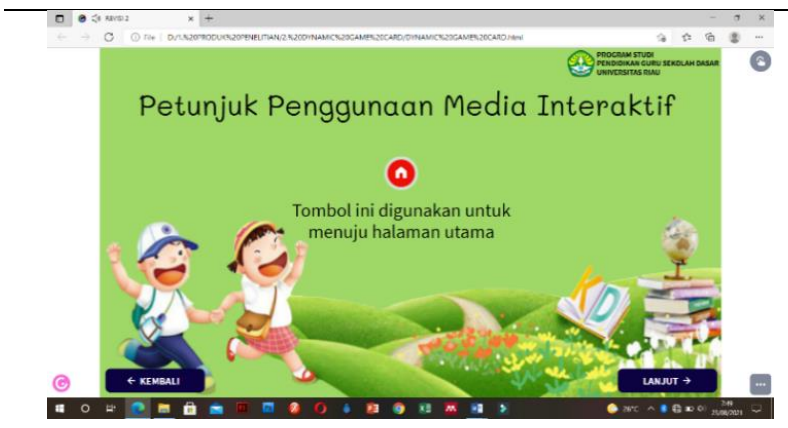

Figure 2. User Guide Page

\section{Explanation}

The game presentation page is designed with a green pattern, landscape illustration, and an image of elementary school students. The whole pattern is designed directly using Genially. The presentation page consists of a welcome sentence, the developer's name, agencies, the next button, and the user manual button. The text is designed with an animation style.

Before playing the number card game, students are directed to the user guide page by clicking the instruction button. This page provides information regarding the use of each button on the media. The information is animated so that the information appears alternately at a predetermined time (Figure 2). 


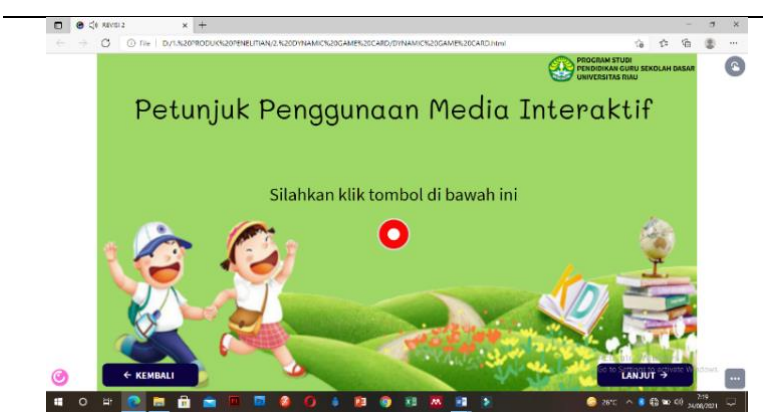

Figure 3. The Button to Move to the Cover Page

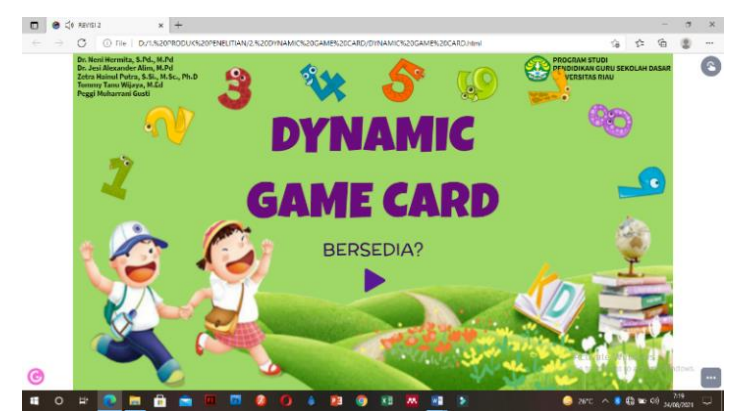

Figure 4. Cover Page

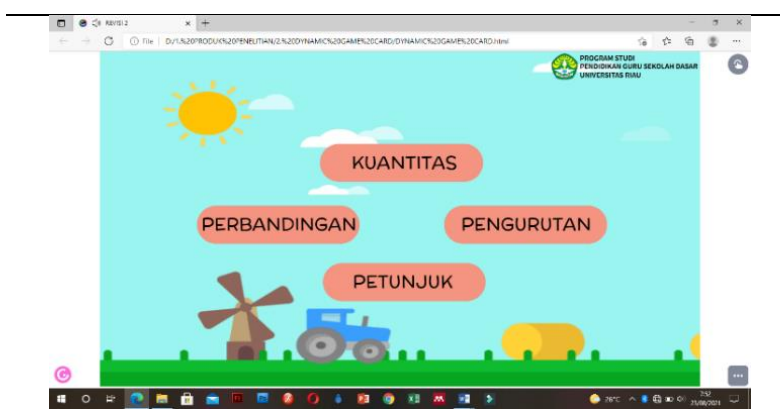

Figure 5. Menu Page

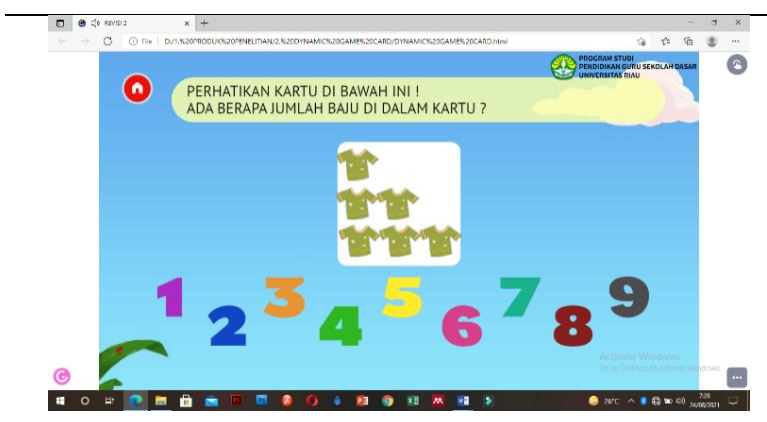

Figure 6. Quantity Menu (Recognizing Numbers)

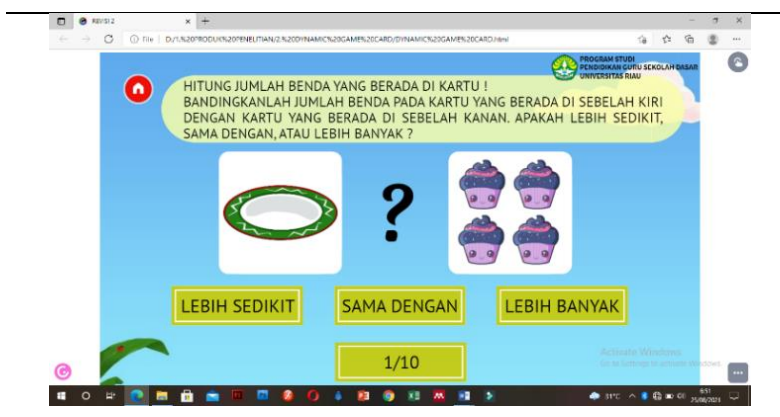

Figure 7. Comparison Menu
At the end of the animation, the user guide page will display a red button. When students click the button, they will be directed to the game cover page (Figure 3 and Figure 4).

The cover page consists of a green pattern, an image of scenery, an illustration of numbers, the title of the material, and a button to start the game. When the purple triangle button is clicked, the students will go to the menu page. There are four buttons on the menu page: a quantity button, a comparison button, a sorting button, and a hint button (Figure 5). Students can answer the questions by clicking the buttons.

When students click the quantity button, they will be given a number recognition game. The command on the quantity button is located at the top careen "Pay attention to the card below. How many items are there in the card?" The quantity menu consists of three questions with different quantities and items, namely clothes, ice cream, and balloons (Figure 6).

When students choose the comparison menu, they will be given two cards with ten different pictures. The instruction reads "Count how many objects are on the card," and "Compare the number of things on the lefthand card to the right-hand card." The instructions are located on the top screen (Figure 7). 


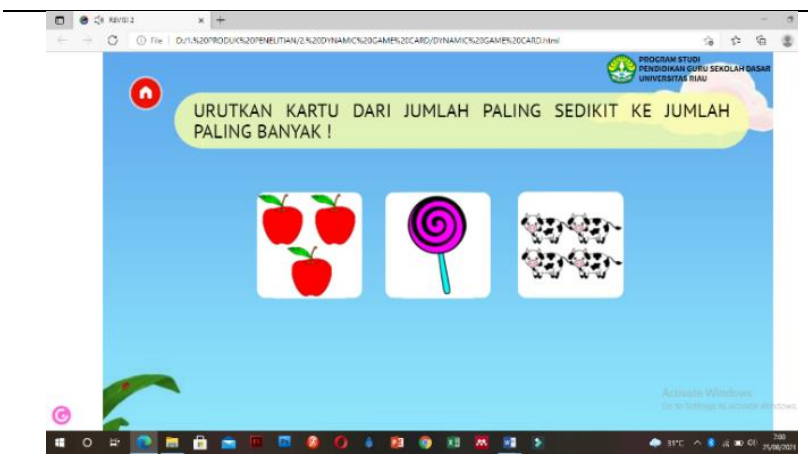

When students choose the sorting menu, they will have to sort cards from the smallest number to the largest number. This game consists of three stages. The first stage is to sort three cards, the second stage is to sort four cards, and the last is to sort five cards (Figure 8).

Figure 8. Sorting Menu Card Game

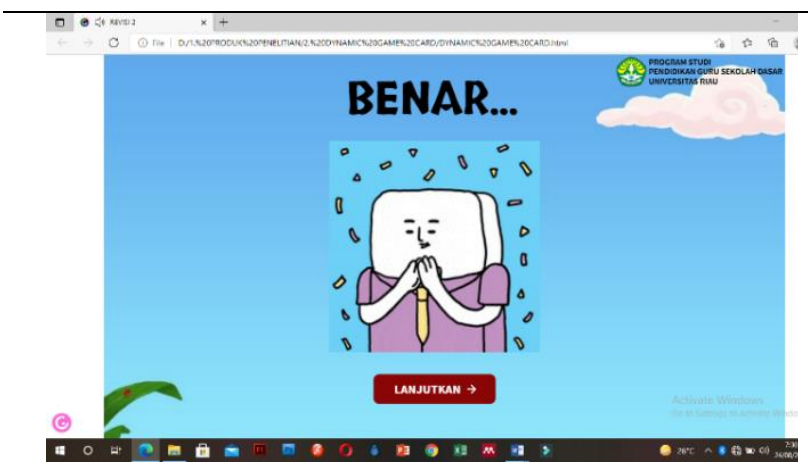

All games have the same flow. When students answer a question incorrectly, it will display animation, and they must repeat the question. If the student got the correct answer, the right answer is animated for the students. The student can click the 'continue' button (Figure 9 and Figure 10).

Figure 9. Correct Answer Animation

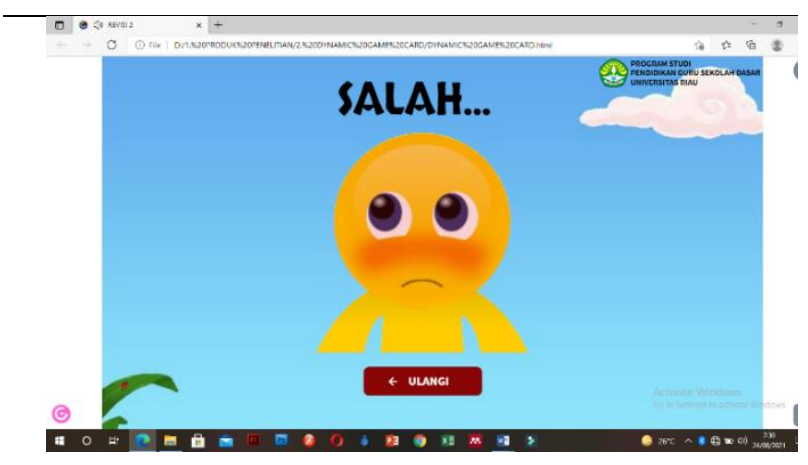

Figure 10. Wrong Answer Animation

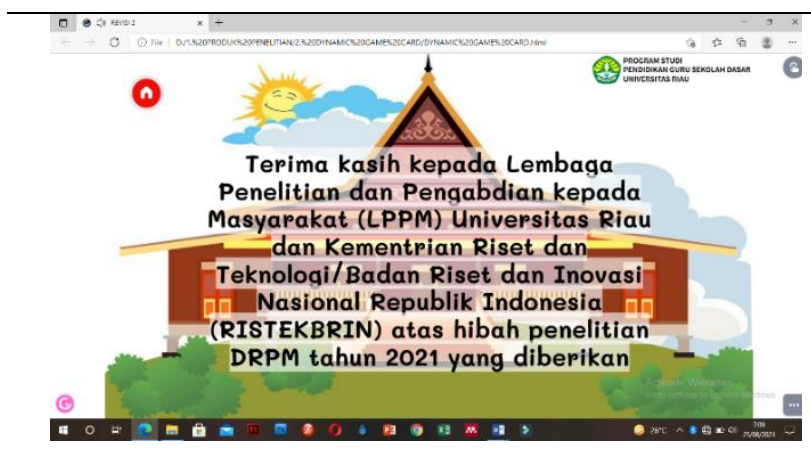

After all the games have been completed and answered correctly, the media displays the closing page with appreciation words to the parties involved (Figure 11). The game can be closed by clicking the cross button on the browser tab.

Figure 11. Closing Page

\section{Experts Validation}

Three media experts and two material experts participated in the validation process. The display/design features and technical components were assessed separately. The material validation instrument had two assessment aspects: pedagogic and content. 
The media experts and material experts provided a score of $64.07 \%$ within the high category. The experts suggested revising by synchronizing the displayed objects. They also suggested paying attention to the command sentences so that they can be understood easily by students.

\section{Preliminary Trial with Three First-Grade Students: One-to-One Evaluation}

The researchers conducted a one-to-one trial with three first-grade elementary school students. The researchers directed the students to use the media. When the students used the media, the researchers guided them. After they succeeded in playing the game, the students were given a response questionnaire on the media. The students stated that they could use the media easily. The colors and the neatly arranged objects made students motivated to learn mathematics. The media made the learning process fun. The responses assured that the media was feasible and could be implemented in schools with more students. The students' responses were based on a questionnaire with 18 statements as follows:

Table 3. Students' Statements

\begin{tabular}{cl}
\hline No. & \multicolumn{1}{c}{ Statements } \\
\hline 1 & I can use this learning media easily; \\
\hline 2 & Menu display and menu descriptions are clear; \\
\hline 3 & The buttons work as they should; \\
\hline 4 & The language is easy to understand; \\
\hline 5 & $\begin{array}{l}\text { The explanations on the comparison of two-unit numbers and the ordering of two } \\
\text { numbers from smallest to largest are easy to understand; }\end{array}$ \\
\hline 6 & Practice questions following the concept being studied; \\
\hline 7 & The colors and pictures make learning more fun; \\
\hline 8 & Learning material using animations or graphics makes it easier for me to grasp concepts. \\
\hline 9 & The lesson presented is neatly arranged; \\
\hline 10 & After using this learning media, I am more motivated to practice mathematics. ; \\
\hline 11 & I can learn using this learning media; \\
\hline 12 & I can control this learning media; \\
\hline 13 & The instructions for learning activities are clearly stated; \\
\hline 14 & Learning by using this media is very interesting; \\
\hline No. & \\
\hline 15 & I can focus on learning mathematics using this learning media; \\
\hline 16 & I can learn more independently using this learning media; \\
\hline 17 & This learning media can help me understand rapidly; \\
\hline 18 & Learning using this interactive learning media is very fun. \\
\hline
\end{tabular}

Five choices were given for each statement item (strongly disagree, disagree, agree, or strongly agree). The students can check one of the choices according to what they feel when using the interactive learning media.

\section{Implementation Stage}

The implementation stage was carried out at SDN 192 Pekanbaru. The first-grade students of class $1 \mathrm{~A}$ were selected as the control class with a total of 26 students. Class 1B was selected as the experimental class with a total number of 20 students. The students operated the media through the link https://bit.ly/3mNlodj. Previously, the students were given a pre-test. After 
learning using this interactive game, the students were given a post-test. The pre-test and posttest consisted of 12 questions.

1) Control Class Data Description

Table 4. The Statistical Calculation of the Control Class

\begin{tabular}{lrrr}
\hline & \multicolumn{1}{c}{ CPreT } & \multicolumn{1}{c}{ CPostT } \\
\hline $\mathrm{N}$ & Valid & 26 & 26 \\
$\mathrm{X}$ & Missing & 0 & 0 \\
Median & 5.96 & 8.54 \\
Mode & 6.00 & 9.00 \\
Std. Dev & 7 & 9 \\
Range & 1.113 & 1.902 \\
Min & 3 & 8 \\
Max & 4 & 4 \\
\hline
\end{tabular}

The statistical calculations were done using the SPSS 26 program. In the control class, the maximum pre-test score was 7 , and the maximum post-test score was 9 . There were three points increase with the median values of 6.0 and 9.0, respectively. However, the minimum scores for each test were 4. Figure 12 shows the students' scores from pre-test to post-test.

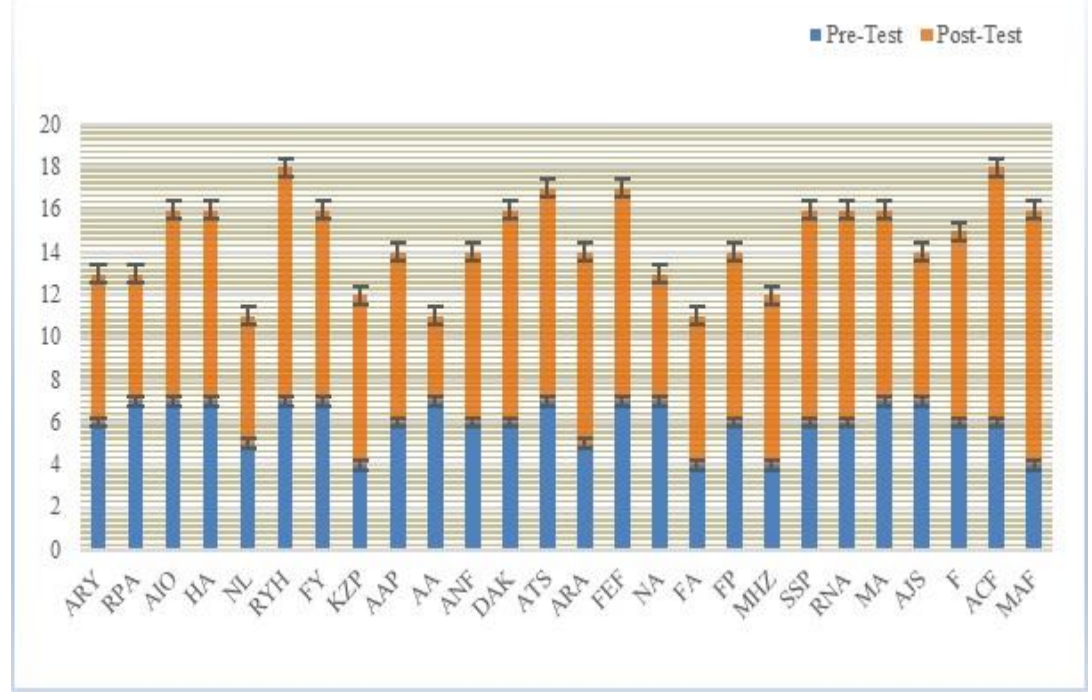

Figure 12. Control Class's Score Recapitulation

2) Experimental Class's Data Description

Table 5. The Statistical Calculation of the Experimental Class

\begin{tabular}{lrrr}
\hline & \multicolumn{2}{c}{ EPreT } & \multicolumn{2}{c}{ EPostT } \\
\hline $\mathrm{N}$ & Valid & 20 & 20 \\
$\mathrm{X}$ & Missing & 0 & 0 \\
Median & 5.95 & 11.75 \\
Mode & 6.00 & 12.00 \\
Std. Deviation & 7 & 12 \\
Range & 1.146 & .550 \\
Min score & 3 & 2 \\
Max score & 4 & 10 \\
\hline
\end{tabular}

The statistical calculations were done using the SPSS 26 program. In the experimental class, the maximum pre-test score was 7 , and the maximum post-test score was 12 . There was a five-point increase with median values of 6.0 and 12.0, respectively. Furthermore, the 
minimum scores increased greatly. Figure 13 shows the students' scores from pre-test to posttest.

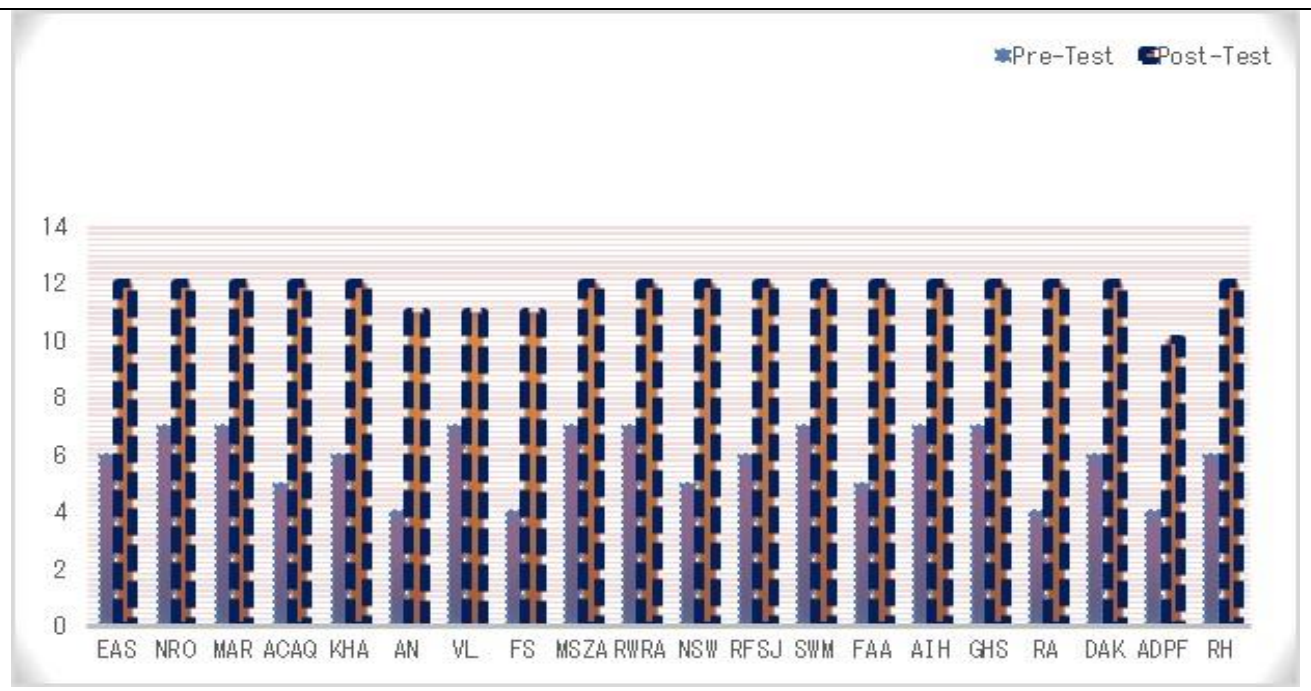

Figure 13. Experimental Class's Score Recapitulation

3) Normality Test

The normality test determines whether or not the data population is normally distributed. The One-Sample Kolmogorov-Smirnov test was employed with a significance level of 0.05 . If the significance is more than $5 \%$ or 0.05 , the data is normally distributed. The decision-making basis is if the significance value is higher than 0.05 , then the data is normally distributed. On the other hand, if the significance value is lower than 0.05 , the data was not normally distributed. The Shapiro Wilk test obtained a significance value of 0.200 , which was higher than 0.05 . Therefore, the data were normally distributed. The calculation results obtained are as follows:

Tabel 6. The Results of the Normality Test in the Control Class

\begin{tabular}{lccccrr}
\hline \multirow{2}{*}{ Control class } & \multicolumn{3}{c}{ Kolmogorov-Smirnov $^{\mathrm{a}}$} & \multicolumn{3}{c}{ Shapiro-Wilk } \\
\cline { 2 - 7 } & Statistic & df & Sig. & Statistic & df & \multicolumn{1}{c}{ Sig. } \\
\hline \multirow{2}{*}{ CPreT } & .248 & 26 & .200 & .811 & 26 & .210 \\
CPostT & .134 & 26 & $.200^{*}$ & .965 & 26 & .504 \\
\hline
\end{tabular}

The pre-test and post-test significance values in the control class were 0.200 , and the Shapiro-Wilk test values were 0.210 and 0.504 ( $p>0.05$ ). The results indicated that the data were normally distributed.

Tabel 7. The Results of the Normality Test in the Experimental Class

\begin{tabular}{lcccccc}
\hline \multirow{2}{*}{ Experimental class } & \multicolumn{3}{c}{ Kolmogorov-Smirnov $^{\mathrm{a}}$} & \multicolumn{3}{c}{ Shapiro-Wilk } \\
\cline { 2 - 8 } & Statistic & df & \multicolumn{1}{c}{ Sig. } & Statistic & df & Sig. \\
\hline EPreT & .267 & 20 & .198 & .783 & 20 & .093 \\
EPostT & .475 & 20 & .200 & .522 & 20 & .107 \\
\hline
\end{tabular}

Based on the calculation results of the normality test, the significance values of the pretest and post-test in the experimental class were 0.198 and 0.200 (Kolmogorov-Smirnov) and 0.930 and 0.107 (Shapiro-Wilk), where the p-value was higher than 0.05. Therefore, the data were normally distributed. 
Tabel 8. Paired Sample t-test

\begin{tabular}{|c|c|c|c|c|c|c|c|c|}
\hline & \multicolumn{5}{|c|}{ Paired Differences } & \multirow{3}{*}{$\mathrm{t}$} & \multirow{3}{*}{ df } & \multirow{3}{*}{$\begin{array}{l}\text { Sig. }(2- \\
\text { tailed) }\end{array}$} \\
\hline & \multirow[t]{2}{*}{ Mean } & \multirow[t]{2}{*}{ Std. Dev } & \multirow[t]{2}{*}{ Std. Error } & \multicolumn{2}{|c|}{$\begin{array}{l}95 \% \text { Confidence Interval of } \\
\text { the Difference } \\
\end{array}$} & & & \\
\hline & & & & Lower & Upper & & & \\
\hline Control CPostT & -2.5769 & 2.2658 & .4444 & -3.4921 & -1.6617 & -5.799 & 25 & .000 \\
\hline $\begin{array}{ll}\text { Experim } & \text { EPreT - } \\
\text { ent } & \text { EPostT }\end{array}$ & -5.800 & .951 & .213 & -6.245 & -5.355 & -27.262 & 19 & .000 \\
\hline
\end{tabular}

Based on the paired sample test output table, the mean value obtained by the control class was -2.5769 , and the mean value obtained by the experimental class was -5800 . The values indicating the average difference between pre-test and post-test were -3.4921 to 1.6617 for the control class and -6.245 to -5.355 for the experimental class (95\% confidence interval of the difference lower and uppers). The t-values were negative, namely -5.799 for the control class and -27,262 for the experimental class. The t-values were negative because the average pre-test score was lower than the average post-test score. In this context, the negative t-values meant positive. It means that there was a difference between the post-test in the experimental class and the control class. Therefore, the developed interactive game was feasible and can improve the first-grade elementary school students' number sense.

This research aimed to design an interactive game to improve first-grade elementary school students' number sense. The product of this research complements the previously developed media to support students' number sense learning, such as research using concrete objects to support students' number sense learning (Anghileri, 2006).

Teachers can also develop and teach this number sense to their students by thinking about activities that make them deal with numbers in different situations. Stanistas Susilowati (2015) argues that students will use number sense when dealing directly with numerical situations. In other words, number sense will develop when it is triggered by a context that requires mathematics to create relationships between numbers. It will make students think about numbers in a different way flexibly. Mathematics competence will develop in students who believe that mathematics is logical and can acquire that sense. Therefore, the material provided must also open up students' horizons so that they can solve problems procedurally.

\section{CONCLUSIONS}

This media was developed by employing the ADDIE development model assisted by the Genially application to develop first-grade elementary school students' number sense. The product was feasible based on the results of three media experts and two material experts, with a score of $64.07 \%$. The media is easy to understand and obtains good responses from the teacher. Based on the results of the implementation, the interactive game can improve students' number sense, as evidenced by the difference between the control class and the experimental class.

Therefore, the interactive design of this game can improve students' numbers. The students were more enthusiastic in the learning process. Therefore, the researchers suggest that teachers use this media in the mathematics learning process in the classroom and at home 
with the parent's guidance. It is also suggested for further researchers to download this learning media for free and then expand the focus. Further researchers can also use Genially to develop other learning media.

\section{ACKNOWLEDGMENT}

The researchers express their gratitude to the Ministry of Research and Technology/National Research and Innovation Agency Indonesia (RISTEKBRIN) for supporting this research under the grant of DRPM 2021 (1378/UN.19.5.1.3/PT.01.03/2021).

\section{AUTHOR CONTRIBUTIONS STATEMENT}

All authors contributed to the design research, product development processes, analyzing data, writing manuscripts, and approving final manuscripts.

\section{REFERENCES}

Anghileri, J. (2006). Teaching number sense, 2nd ed. London: Continuum.

Baharuddin, B. (2018). ADDIE model application promoting interactive multimedia. IOP Conference Series: Materials Science and Engineering, 306(1).

Cabang, R. (2009). Desain intruksional: Pendekataan ADDIE. Jilid. 722.

Chen, Y. L. (2020). Students' attitude toward learning and practicing english in a VR environment. In Lecture Notes in Computer ScienceSpringer International Publishing.

Dzenskevich. (2020). Membuat poster astronomi interaktif dalam layanan online thinglink dan secara umum. International Research Journal, 4(94).

Harits, M., Sujadi, I., \& Slamet, I. (2019). Technological, pedagogical, and content knowledge math teachers: To develop 21st century skills students. Journal of Physics: Conference Series, 1321(3).

Hermita, N., Suhandi, A., Syaodih, E., Samsudin, A., Marhadi, H., Sapriadil, S., Zaenudin, Z., Rochman, C., Mansur, M., \& Wibowo, F. C. (2018). Level conceptual change preservice elementary teachers on electric current conceptions through visual multimedia supported conceptual change. Journal of Physics: Conference Series, 1013(1), 1-7.

Kulsum, S. I., Hidayat, W., Wijaya, T. T., \& Kumala, J. (2019). Analysis on high school students' mathematical creative thinking skills on the topic of sets. Jurnal Cendekia: Jurnal Pendidikan Matematika, 03(02), 431-436.

Kurniasi, E. R., Y, Y., \& Karennisa, F. (2020). Analisis soal ulangan harian matematika kelas IX SMP Negeri 1 Toboali. Jurnal Ilmu Pendidikan (JIP) STKIP Kusuma Negara, 12(1), 43-52.

Lainufar, Mailizar, \& Johar, R. (2020). A need analysis for the development of augmented reality based-geometry teaching instruments in junior high schools. Journal of Physics: Conference Series, 1460(1), 1-7.

Losada, M. F. D. (2017). Are mathematics competitions changing the mathematics that is being done and the way mathematics is done?. In Competitions for young mathematicians, 329-350.

Manuel, P. M., Pilar, A. M., María Dolores, R. M., MP, D., Sara, P., \& M. Pilar, M. J. (2019). Characterization of biodiesel using virtual laboratories integrating social networks and 
web app following a ubiquitous- and blended-learning. Journal of Cleaner Production, 215, 399-409.

Mcintosh, A., Bana, J., \& Farreii, B. (1997). Assessing number sense: Collaborative initiatives in Australia, United States, Sweden and Taiwan AIistair McIntosh, Jack Bana \& Brian FarreII Edith Cowan University. MERGA 20, 324-330.

McIntosh, A., Reys, B. J., \& Reys, R. E. (1992). A proposed framework for examining basic number sense. For the Learning of Mathematics 12, 3, 2-8.

Mukminin, A., Habibi, A., Muhaimin, Asrial, Haryanto, E., Setiono, P., \& Sofyan. (2019). Vocational technical high school teachers' beliefs towards ICT for the 21 st century education: Indonesian context. Problems of Education in the 21 st Century, 77(1), 22-38.

Musskopf, Â., Barbosa, D. N. F., Bassani, P. B. S., \& Jefferies, A. (2019). Using digital resources to boost english writing development. Springer Nature Switzerland AG 2019, 337-348.

Mutmainnah, A., Putra, Z. H., \& Syahrilfuddin, S. (2021). The relationship between fifth grade students ' number sense and their mathematical problem solving. ElementaryEdu Journal of Elementary Education, 5(1), 66-79.

Nite, S. (2017). Using polya' s problem solving process in the mathematics classroom to prepare to task. Pedagogy and Content in Middle and High School Mathematics, 233235.

Nur, M. (2004). Teori-teori perkembangan kognitif. Surabaya: PSMS Unesa.

Pereira, J., Wijaya, T. T., Ying, Z., \& Purnama, A. (2021). Learning points , lines , and plane geometry with Hawgent dynamic mathematics software. Journal of Physics: Conference Series, 1882(1), 012057.

Prabowo, A., Anggoro, R. P., Adiyanto, R., \& Rahmawati, U. (2018). Interactive multimediabased teaching material for trigonometry. Journal of Physics: Conference Series, 1097(1), 1-9.

Putra, Z. H., Wulandari, W., Alpusari, M., \& Hermita, N. (2021). Developing a dynamic number card game to support students' number sense: A preliminary study. Proceedings - 2021 1st International Conference on Technology Enhanced Learning in Higher Education, TELE 2021, 978, 107-110.

Rahmah, N. (2013). Hakikat pendidikan matematika. Al-Khwarizmi, 2, 1-10.

Rohaeti, E.E., Nurjaman, A., Sari, I. P., Bernard, M., \& Hidayat, W. (2019). Developing didactic design in triangle and rectangular toward students mathematical creative thinking through Visual Basic for PowerPoint. Journal of Physics: Conference Series, 1157(4).

Rohaeti, Euis Eti, Bernard, M., \& Primandhika, R. B. (2019). Developing interactive learning media for school level mathematics through open-ended approach aided by visual basic application for excel. Journal on Mathematics Education, 10(1), 59-68.

Ruqoyyah, S., Murni, S., \& Wijaya, T. T. (2020). The effect of VBA for microsoft excel as teaching material to improve prospective elementary school teachers' mathematical conceptual understanding. Mimbar Sekolah Dasar, 7(2), 251-268.

Sood, S., \& Mackey, M. (2015). Examining the effects of number sense instruction on mathematics competence of kindergarten students. International Journal of Humanities Social Sciences and Education (IJHSSE), 2(2), 2349. 
Sugiyono. (2019). Metode penelitian pendidikan (kuantitatif, kualitatif, kombinasi, $R \& D$ dan penelitian pendidikan). Alfabeta.

Susilowati, T. (2015). Kemampuan number sense melalui metode learning by playing. Jurnal Pendidikan Dasar, 6(2), 339-350.

Vidergor, H. E. (2021). Effects of digital escape room on gameful experience, collaboration, and motivation of elementary school students. Computers \& Education, 166, 104156.

Wijaya, T. T., Jianlan, T., \& Purnama, A. (2020). Developing an interactive mathematical learning media based on the TPACK framework using the hawgent dynamic mathematics software. Emerging Technologies in Computing, 318-328.

Wijaya, T. T., Purnama, A., \& Tanuwijaya, H. (2020). Pengembangan media pembelajaran berdasarkan konsep tpack pada materi garis dan sudut menggunakan hawgent dynamic mathematics software. JPMI - Jurnal Pembelajaran Matematika Inovatif, 3(3), 205214.

Wijaya, T. T., Ying, Z., Chotimah, S., Bernard, M., Zulfah, \& Astuti. (2020). Hawgent dynamic mathematic software as mathematics learning media for teaching quadratic functions. Journal of Physics: Conference Series, 1592(1), 1-8.

Wijaya, T. T., Zulfah, Z., Hidayat, A., Akbar, P., Arianti, W., \& Asyura, I. (2020). Using VBA for microsoft excel based on 6-questions cognitive theory in teaching fraction. Journal of Physics: Conference Series, 1657(1), 012078.

Yuniarni, D., Sari, R. P., \& Atiq, A. (2020). Pengembangan multimedia interaktif video senam animasi berbasis budaya khas Kalimantan Barat. Jurnal Obsesi: Jurnal Pendidikan Anak Usia Dini, 4(1), 280-294. 